Research Article

\title{
Microbiological Monitoring of the Environment Using the “Association Rules" Approach and Disinfection Procedure Evaluation in a Hospital Center in Morocco
}

\author{
Rachid Flouchi $\mathbb{D}^{1,2}$ Abderrahim Elmniai $\mathbb{D}^{1,3,4}$ Mohamed El Far $\mathbb{D}^{1},{ }^{5}$ Ibrahim Touzani $\mathbb{D},{ }^{1,2}$ \\ Naoufal El Hachlafi $\left({ }^{\circ},{ }^{1}\right.$ and Kawtar Fikri-Benbrahim $\left(^{1}{ }^{1}\right.$ \\ ${ }^{1}$ Laboratory of Microbial Biotechnology and Bioactive Molecules, Science and Technologies Faculty, \\ Sidi Mohamed Ben Abdellah University, Fez, Morocco \\ ${ }^{2}$ High Institute of Nursing Professions and Health Techniques Annex Taza, Fez, Morocco \\ ${ }^{3}$ Human Pathology, Biomedicine and Environment Laboratory, Faculty of Medicine and Pharmacy, \\ Sidi Mohamed Ben Abdellah University, Fez, Morocco \\ ${ }^{4}$ Provincial Laboratory of Epidemiology and Environmental Hygiene, DMS Taza, Taza, Morocco \\ ${ }^{5}$ Laboratory of Applied Physics, Computer Science and Statistics Sciences Faculty Dhar El Mahraz, \\ Sidi Mohamed Ben Abdellah University, Fez, Morocco
}

Correspondence should be addressed to Kawtar Fikri-Benbrahim; kawtar.fikribenbrahim@usmba.ac.ma

Received 15 April 2021; Revised 12 May 2021; Accepted 23 June 2021; Published 5 July 2021

Academic Editor: Arun S. Kharat

Copyright $\odot 2021$ Rachid Flouchi et al. This is an open access article distributed under the Creative Commons Attribution License, which permits unrestricted use, distribution, and reproduction in any medium, provided the original work is properly cited.

Background. The hospital environment, especially surfaces and medical devices, is a source of contamination for patients. Objective. This study carried out, to the best of our knowledge, for the first time at Taza Hospital in Morocco aimed to assess the microbiological quality of surfaces and medical devices in surgical departments and to evaluate the disinfection procedure in time and space. Methods. Samples were taken by swabbing after cleaning the hospital surface or medical device, to isolate and identify germs which were inoculated on semiselective culture media then identified by standard biochemical and physiological tests, using the analytical profile index (API) galleries. Moreover, the association rules extraction model between sites on the one hand and germs on the other hand was used for sampling. Results. The study showed that $83 \%$ of the samples have been contaminated after biocleaning. The most contaminated services have been men's and women's surgeries. $62 \%$ of isolated germs have been identified as Gram-positive bacteria, 29\% as Gram-negative bacteria, and $9 \%$ as fungi. Concerning the association rules extraction model, a strong association between some contaminated sites and the presence of germ has been found, such as the association between wall and nightstand and door cuff, meaning that the wall and nightstand contamination is systematically linked to that of the door cuff. The disinfection procedure efficacy evaluation has enabled suggesting renewing it each $4 \mathrm{~h}$. Conclusion. Microbiological monitoring of surfaces is necessary at hospital level through the use of the association rule extraction model, which is very important to optimize the sampling, cleaning, and disinfection site scenarios of the most contaminated ones.

\section{Introduction}

The main prerogative of hospital institutions is to provide care for patients. Unfortunately, some complications can emerge in certain cases as nosocomial infections (NAI), which include any infectious event related to the individuals' care. These infections affect approximately $5 \%$ to $10 \%$ of patients in developed countries but the risk is 2 to 20 times higher in developing countries [1]. The presence and increase of these infections induce an extension in the length of stay of patients in hospital, overuse of antibiotics leading sometimes to the emergence of resistant microorganisms, increased costs and expenses, either for the patient or the hospital, and a high mortality rate [2].

Among the main causes of these infections, the patient's environment, particularly the hospital rooms' surfaces and 
architecture, as well as the medical or accommodation equipments frequently used, presents a risk of germ's transmission and contamination by germs in the hospital environment [3]. Indeed, surfaces in the immediate vicinity of patients are frequently contaminated by the hands of hospital patients and health care professionals and are classified as high-contact surfaces [4]. The most simple example concerns pill boxes which have been reported to contain Staphylococcus species (S. captis, S. epidermis, S. hominis...), Corynebacterium striatum, Streprococcus sanguinis, and S. oralis, representing thereby a source of high cross-contamination in hospitals and a risk factor for patients [5]. This risk is linked to the ability of coagulasenegative Staphylococcus species to produce a slimy biofilm enabling their adhesion to medical devices such as prosthetic valves and catheters which makes them the most common cause of prosthetic valve endocarditis, on the one hand [6]. Corynebacterium striatum gaining resistances to many antibiotics [7] has recently been recognized as an emerging pathogen, particularly in a nosocomial setting [8] where it could result in sepsis, on the other hand. Finally, S. sanguinis is also a common cause of subacute bacterial endocarditis; and $S$. oralis are opportunistic pathogens.

Furthermore, the ability of microorganisms to persist on environmental surfaces in hospitals varies greatly depending on the individual's biological factors, and the presence of organic matter or moisture on surfaces; moreover, these microorganisms causing nosocomial infections can remain alive for several weeks to months on dry surfaces [9]. Thus, several studies have shown that large numbers of germs have been isolated from door cuff and hospital floors [10]. Indeed, several types of germs of nosocomial origin have been isolated from surfaces and have shown an innate ability to survive on high-contact surfaces, such as methicillin-resistant Staphylococcus aureus [11], Klebsiella pneumoniae [12], coagulasenegative Staphylococci [13], and Acinetobacter baumannii [14].

Among the most well-known nosocomial infections, surgical site infections (SSI) are ranked second to urinary tract infections [15]. These SSIs develop from environment in the operating rooms during surgery through direct and multiple contacts between patients. The level of surface contamination in hospital wards differs according to the surface's and/or room's types, or the nature of hygiene in a specific unit [16].

Therefore, Centers for Disease Control and Prevention (CDC) have recommended the implementation of procedures, through the use of various monitoring tools that ensure effective cleaning and consistent disinfection of surfaces located close to the patient or likely touched by the patient and the health care professionals [17]. However, there are few studies in the literature on the actual assessment of environmental cleanliness in Moroccan hospitals. In this context, the purpose of this study is to identify and evaluate the pathogenic bacterial contamination of surfaces, medical equipment, and technical medical equipment in surgical departments in a hospital center in Taza (Morocco), to look for the association rules between germs and sampling points, and finally to evaluate the disinfection procedure using three selected disinfectants.

\section{Materials and Methods}

2.1. Study Site. Our study was carried out, during 12 months from June 2018 to May 2019, in the specialized surgery departments, at the provincial hospital of Taza (Fez-Meknes region, North Eastern Morocco) having a bedding capacity of 317 beds.

2.2. Sampling Point and Method. Microbiological sampling of surfaces was carried out according to ISO 14698-1 [18] and concerned the surfaces of patient wards and operating theaters. It was carried out outside of human activities and in postcleaning in the hospital ward and between surgical operations in the operating theaters. For this purpose, a surface area of $25 \mathrm{~cm}^{2}$ has been rubbed with a sterile cotton swab moistened by Brain Heart Infusion BHI, using the method of repeated striations in two zigzag directions. In order to obtain representative results, the sampling from each site was repeated three times [19].

The selected points were those closest to the patients and most frequently used in the hospital ward (bed rails, nightstand, ground, walls, and door cuff), and in the operating theater (operating table, wall, floor, operating theater, electric scalpel, and trolleys). The samples taken, 85 in total, were rapidly transported in a cooler, kept at $4^{\circ} \mathrm{C}$, to the public health laboratory of the delegation Taza health ministry.

2.3. Cultivation, Isolation, and Identification of Germs. Culture and isolation have been performed by inoculating semiselective culture media: Mac Conkey (for Gram-negative bacilli and Enterobacteriaceae), Chapman (for Staphylococci and Micrococci), Cetrimide Agar (Pseudomonas aeruginosa, Klebsiella, and Acinetobacter), EMB for Escherichia coli, Blood Agar and Slanetz Bartley for Streptococci, and Sabouraud added with chloramphenicol for fungi (moulds and yeasts).

Inoculated Petri dishes were incubated at $30-37^{\circ} \mathrm{C}$ for 24 to 48 hours for bacterial cultures, and at $28-32^{\circ} \mathrm{C}, 5$ to 7 days for fungi. The identification of bacteria was carried out according to the classical bacteriological methods, while macroscopic and microscopic examinations were carried out for moulds.

Hence, bacterial identification was based on morphological and biochemical characteristics. The preliminary identification tests concern colony appearance and microscopic examination after Gram staining for all isolated strains, and then lactose fermentation and oxydase activity were tested for bacilli selected on Mac Conkey agar; mannitol fermentation, catalase activity, coagulase, and DNase tests were performed for cocci isolated on chapman medium; a catalase test and a verification on Bile Esculin Agar (BEA) were performed for bacteria of the genus Streptoccus, while lactose and mannitol fermentations, catalase, and oxydase activities and motility were tested for bacteria isolated on cetrimide.

Thereafter, identification was continued by standard biochemical and physiological tests, carried out by the 
analytical profile index (API) galleries (API $20 \mathrm{E}^{\circledR}$ and API 20 $\mathrm{NE}$ ), based on standardized, miniaturized biochemical tests enabling easy and fast identification of relevant bacteria. These tests are carried out in wells containing dehydrated substrates to detect different enzymatic activities of the tested microorganisms, related to the fermentation of some selected sugars, and to the catabolism of certain substances such as proteins, amino acids, or carboxylic acids. Briefly, bacterial suspensions with a suitable density are distributed in each well of the microgallery and the system is incubated at a suitable temperature (generally $30-37^{\circ} \mathrm{C}$ for $24-48 \mathrm{~h}$ ). The metabolites produced during the incubation period are brought out by spontaneous color changes or revealed by the addition of specific reagents. The obtained results are compiled according to a standard table of reactions to obtain a strain's profile number. Finally, analytical catalogs are used to identify the bacterial species, while ensuring the identification authenticity.

Concerning fungal identification, a macroscopic study of colony characteristics enabled differentiating between fungi and yeasts grown on Sabouraud + chloramphenicol medium; then the filamentation test was performed by microscopic examination to confirm the presence of Candida for colonies having yeasts characteristics.

All identified strains were kept in glycerol tubes at $-18^{\circ} \mathrm{C}$.

\subsection{Extraction Model Approach of the Association Rules.} It is a model based on a transactional database, where items are represented in columns and transactions in lines. To adopt this model in our case study, we went through the realization of a hollow matrix where rows represent the isolated germs and columns represent the sampling points; this matrix serves as a source of the transactional database.

The technique adopted in this study consists of two steps:

(i) First, the algorithm a priori, which is part of the DATA maining (associative) algorithm, has been applied [20]. It remains always the most popular used algorithm thanks to its performance and efficiency. The algorithm performance parameters in our case: $\min$ support $25 \%$, min confidence $75 \%$.

(ii) Second, our algorithm extracts association rules from different points of the chosen samples and the isolated germs according to the previous indicated parameter min of confidence index. To have important association rules, the left indicator which is strictly superior to 1 was applied.

2.5. Evaluation of the Effectiveness of the Disinfection Procedure in Time and Space. To evaluate the disinfection procedure, the most contaminated points have been chosen (ground surface), and 3 samples were taken (ground surfaces 1,2 , and 3) before and after disinfection by the studied disinfectants. The samples have been repeated each two hours to perform germs identification.

Three selected disinfectants belonging to the quaternary ammonium family were used to identify and evaluate their antibacterial activity.

\section{Results}

Based on 85 samples, 70 have been used to identify germs in surfaces and medical devices and 15 to assess the inhibitory potential of disinfectants against microorganisms. For the 70 surveillance samples taken from different points close to the patient, either in the hospital ward or operating theater, a contamination percentage of $83 \%(n=58)$ has been found, compared to $17 \%(n=12)$ uncontaminated samples.

The most contaminated sampling sites have been, respectively, the floors (26\%), bed barriers and door handles (17\%), and walls and bedside tables (13\%), while the other sites represent less than 5\% (Figure 1).

3.1. Distribution of Germs according to Sampling Points. A total of 27 microorganisms have been isolated from different sampling points consisting of 9 Gram-positive bacteria, $16 \mathrm{Gram}$-negative bacteria, and 2 fungi (yeasts and moulds). Concerning these germs' distribution, a predominance of Gram-positive bacteria has been noticed by $62 \%$, followed by Gram-negative bacteria (29\%) and then fungi (9\%). The majority of these species belong to Staphylococcus species (40\%), distributed between coagulase-negative Staphylococci (22\%) and Staphylococcus aureus (18\%), followed by Streptococci species (11\%), Pseudomonas luteola, Klebsiella pneumoniae, and Escherichia coli (4\%), and then Enterococcus spp., Bacillus spp., Proteus mirabilis (3\%), Pantoea spp., Stenotrophomonas maltophilia, Candida albicans, and Gram-negative cocci (2\%). The other bacteria represent less than or almost $1 \%$, while the $9 \%$ of the fungi are distributed between yeasts (6\%) and moulds (3\%) (Figure 2). Concerning the distribution of these germs according to the studied departments, a great germs diversification was observed according to each department. From the 27 isolated germs, 18 germs were isolated in the female surgery department, 13 in male surgery, 10 in gynecological-obstetrics, 9 in children's surgery, and 4 in the operating theater (Figure 3).

The distribution of isolated germs, according to the five studied departments, has shown their predominance in male and female surgery with a rate of $17 \%$, followed by gynecological-obstetrics $11 \%$, operating theater $9 \%$, and then children's surgery $8 \%$. Moreover, the Staphylococcus and Streptococcus species were the most frequent in all surgery departments (Figure 3).

3.2. Model Approach for Extracting Association Rules. Based on the application of the "algorithm a priori" on our transactional database (with min support $25 \%$, min confidence $75 \%$, and lift greater than 1 ), the obtained results show a strong association of contamination between the following:

(i) Wall and nightstand and door cuff at $100 \%$ confidence or with $100 \%$ confidence

(ii) Ground and door cuff and bed rails with a confidence rate of $87 \%$ 


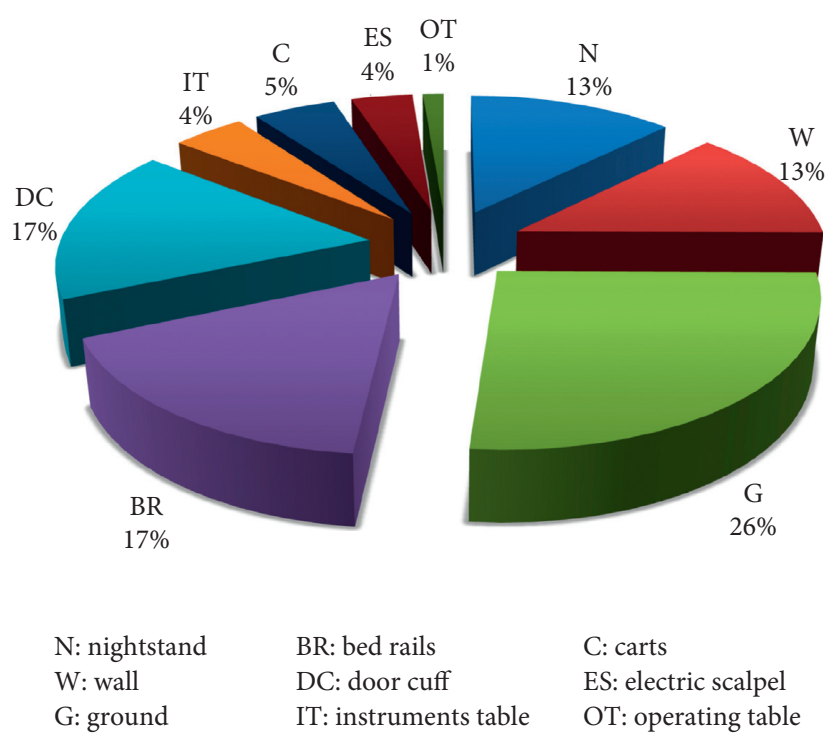

FIgUre 1: Contamination rate of the studied sampling sites.

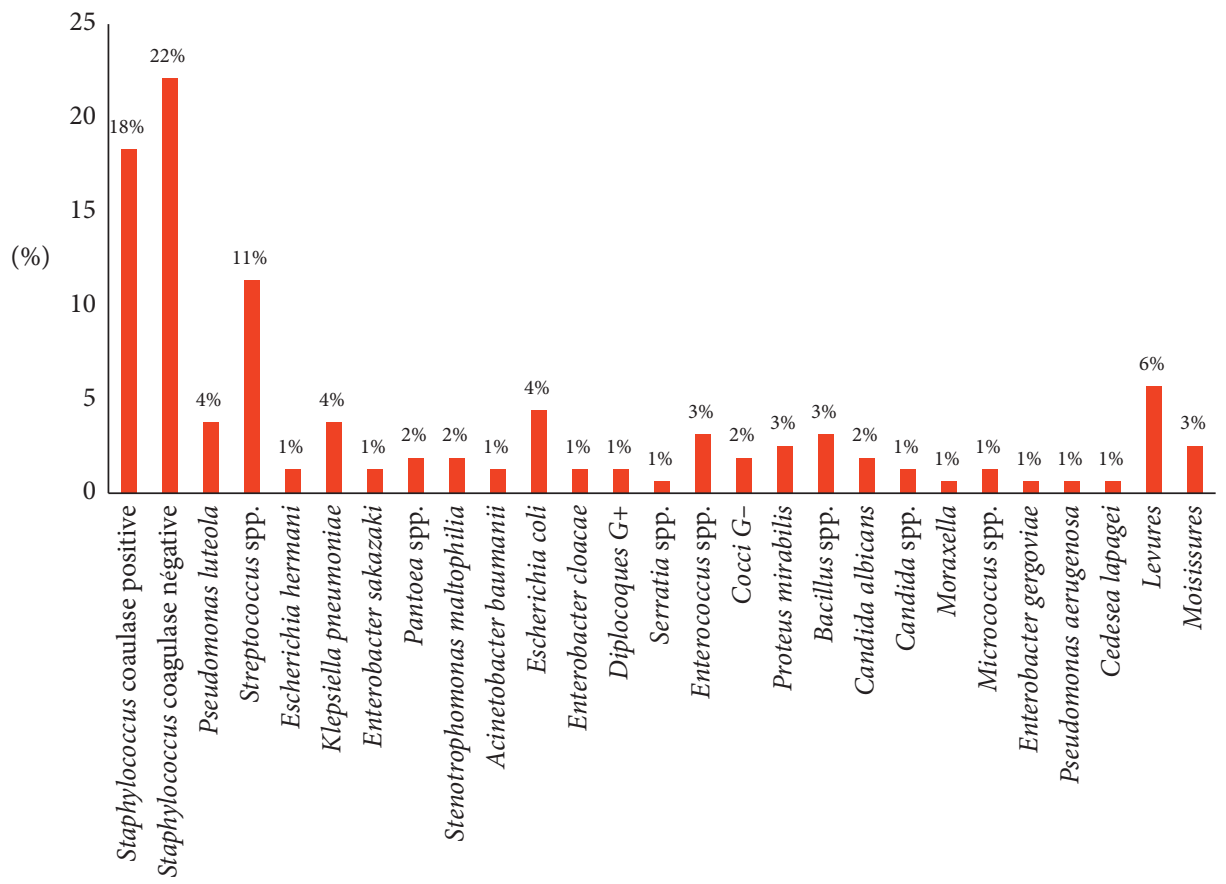

FIGURE 2: Distribution of isolated germs in the sampling sites.

(iii) Door cuff and nightstand and bed rails on the one hand and the ground on the other hand in the confidence $77.7 \%$

The quality of the lift indicator is strictly higher than 1 , which means the importance and quality of the association rule used (Table 1 ).

Concerning the isolated germs, strong associations of microorganism's presence have been found between Pseudomonas luteola and coagulase-negative Staphylococci within a confidence interval of $100 \%$, between Staphylococcus aureus and Streptococcus spp. and coagulase-negative
Staphylococci with 90\% confidence, and between Escherichia coli and Staphylococcus aureus on the one hand and coagulase-negative Staphylococci on the other hand, with respective confidence of $85 \%$ and $71 \%$. Furthermore, the quality of the lift indicator of our model is also strictly superior to 1, which confirms the importance and quality of the association rule used (Table 2).

3.3. Evaluation of the Disinfection Procedure. Before disinfection, multiple and diversified presences of microorganisms have been found. Then, just after disinfection, a total 


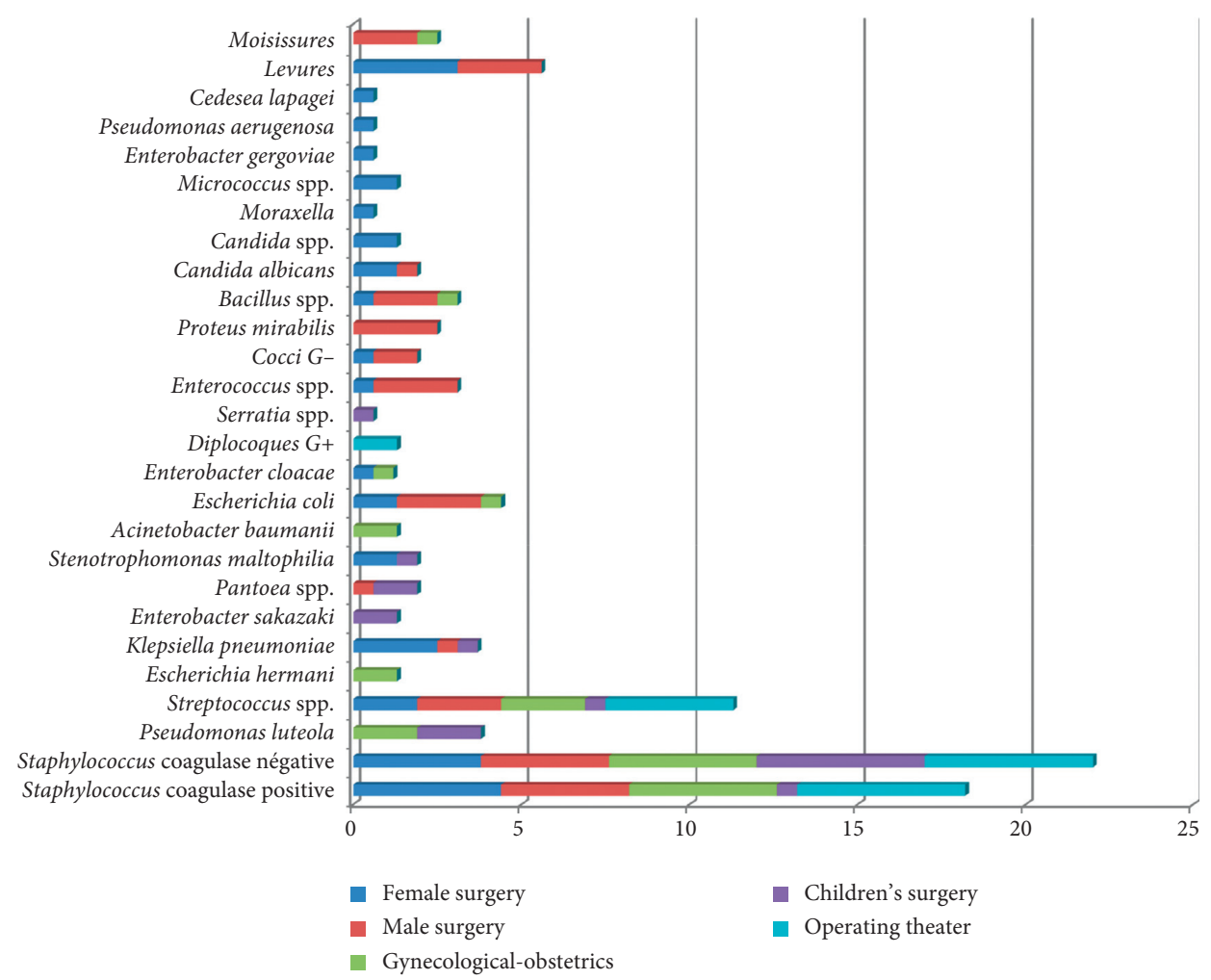

FIGURE 3: Distribution of isolated germs in the sampling sites according to each department.

TABLE 1: The extraction model of the association rule between sampling points.

\begin{tabular}{lccccccccc}
\hline Antecedents & Consequents & $\begin{array}{c}\text { Antecedent } \\
\text { support }\end{array}$ & $\begin{array}{c}\text { Consequent } \\
\text { support }\end{array}$ & Support & Confidence & Lift & Leverage & Conviction \\
\hline Door cuff & Nightstand & 0.407407 & 0.555556 & 0.333333 & 0.818182 & 1.472727 & 0.106996 & 2.444444 \\
Door cuff & Wall & 0.407407 & 0.444444 & 0.296296 & 0.727273 & 1.636364 & 0.115226 & 2.037037 \\
Door cuff & Ground & 0.407407 & 0.666667 & 0.296296 & 0.727273 & 1.090909 & 0.024691 & 1.222222 \\
Door cuff & Bed rails & 0.407407 & 0.555556 & 0.333333 & 0.818182 & 1.472727 & 0.106996 & 2.444444 \\
Wall, door cuff & Nightstand & 0.296296 & 0.555556 & 0.259259 & 0.875000 & 1.575000 & 0.094650 & 3.555556 \\
Wall, nightstand & Door cuff & 0.259259 & 0.407407 & 0.259259 & 1.000000 & 2.454545 & 0.153635 & inf \\
Door cuff, nightstand & Wall & 0.333333 & 0.444444 & 0.259259 & 0.777778 & 1.750000 & 0.111111 & 2.500000 \\
Door cuff, night stand & Bed rails & 0.333333 & 0.555556 & 0.259259 & 0.777778 & 1.400000 & 0.074074 & 2.000000 \\
Door cuff, bed rails & Nightstand & 0.333333 & 0.555556 & 0.259259 & 0.777778 & 1.400000 & 0.074074 & 2.000000 \\
Night stand, bed rails & Door cuff & 0.333333 & 0.407407 & 0.259259 & 0.777778 & 1.909091 & 0.123457 & 2.666667 \\
Ground, door cuff & Bed rails & 0.296296 & 0.555556 & 0.259259 & 0.875000 & 1.575000 & 0.094650 & 3.555556 \\
Ground, bed rails & Door cuff & 0.333333 & 0.407407 & 0.259259 & 0.777778 & 1.909091 & 0.123457 & 2.666667 \\
Door cuff, nightstand & Ground & 0.333333 & 0.666667 & 0.259259 & 0.777778 & 1.166667 & 0.037037 & 1.500000 \\
\hline
\end{tabular}

absence of germs following the use of the 3 selected disinfectants has been shown. Two hours after disinfection, the presence of Staphylococcus aureus has been observed in ground surface 1 (disinfected with disinfectant 1), and Streptococcus bacterial strains have been found in ground surfaces 2 and 3 (disinfected with disinfectants 2 and 3 ).

But, four hours after disinfection, the samples have shown the presence and diversification of bacteria in the 3 sampling sites, and after 6 hours multiplication and diversification of bacteria and the presence of fungi (yeasts) have been noticed (Table 3 ). (i) Disinfectant 1 based on quaternary ammonium: didecyl methyl polyoxyethyl ammonium propionate as active substance.

(ii) Disinfectant 2 based on didecyl dimethyl ammonium chloride (CAS N: 7173-51-5): 3.5\% w/w N-(3aminopropyl)-N-dodecylpropane-1, 3-diamine (CAS N: 2372-82-9): 5.5\% w/w, nonionic surfactants, EDTA and salts, allergen-free fragrance labeling.

(iii) Disinfectant 3 based on nonionic surfactant, didecyl dimethyl ammonium chloride CAS no. 7173-51-5 
TABLE 2: The extraction model of the association rule between isolated germs.

\begin{tabular}{lccccccccccc}
\hline Antecedents & Consequents & $\begin{array}{c}\text { Antecedent } \\
\text { support }\end{array}$ & $\begin{array}{c}\text { Consequent } \\
\text { support }\end{array}$ & Support & Confidence & Lift & Leverage Conviction \\
\hline $\begin{array}{l}\text { Staphylococcus aureus } \\
\text { Coagulase-negative }\end{array}$ & $\begin{array}{c}\text { Coagulase-negative } \\
\text { Staphylococci } \\
\text { Staphylococci }\end{array}$ & 0.58 & 0.70 & 0.50 & 0.862069 & 1.231527 & 0.0940 & 2.175 \\
$\begin{array}{l}\text { Staphylococcus } \\
\text { aureus }\end{array}$ & 0.70 & 0.58 & 0.50 & 0.714286 & 1.231527 & 0.0940 & 1.470 \\
Streptococcus spp. & $\begin{array}{c}\text { Staphylococcus } \\
\text { aureus }\end{array}$ & 0.36 & 0.58 & 0.22 & 0.611111 & 1.053640 & 0.0112 & 1.080 \\
$\begin{array}{l}\text { Escherichia coli } \\
\text { Staphylococcus } \\
\text { aureus }\end{array}$ & 0.14 & 0.58 & 0.12 & 0.857143 & 1.477833 & 0.0388 & 2.940 \\
$\begin{array}{l}\text { Pseudomonas luteola } \\
\text { Coagulase-negative } \\
\text { Staphylococcus }\end{array}$ & 0.12 & 0.70 & 0.12 & 1.000000 & 1.428571 & 0.0360 & inf \\
$\begin{array}{l}\text { Streptococcus spp. } \\
\text { Coagulase-negative } \\
\text { Staphylococcis }\end{array}$ & 0.36 & 0.70 & 0.28 & 0.777778 & 1.111111 & 0.0280 & 1.350 \\
$\begin{array}{l}\text { Escherichia coli } \\
\text { Coagulase-negative } \\
\text { Staphylococci }\end{array}$ & 0.14 & 0.70 & 0.10 & 0.714286 & 1.020408 & 0.0020 & 1.050 \\
$\begin{array}{l}\text { Staphylococcus aureus, } \\
\text { Streptococcus spp. }\end{array}$ & $\begin{array}{c}\text { Coagulase-negative } \\
\text { Staphylococci }\end{array}$ & 0.22 & 0.70 & 0.20 & 0.909091 & 1.298701 & 0.0460 & 3.300 \\
$\begin{array}{l}\text { Streptococcus spp., } \\
\text { Coagulase-negative }\end{array}$ & $\begin{array}{c}\text { Staphylococcus } \\
\text { Staphylococci }\end{array}$ & 0.28 & 0.58 & 0.20 & 0.714286 & 1.231527 & 0.0376 & 1.470 \\
\hline
\end{tabular}

TABLE 3: Evaluation of the disinfection procedure according to time and contaminated points.

\begin{tabular}{|c|c|c|c|}
\hline & & Sampling points & \\
\hline & Sampling point 1 & Sampling point 1 & Sampling point 1 \\
\hline \multirow[t]{2}{*}{ Before using disinfectant } & $\begin{array}{l}\text { (i) Staphylococcus aureus } \\
\text { (ii) Streptococcus spp. } \\
\text { (iii) Pantoea spp. } \\
\text { (iv) Yeasts }\end{array}$ & $\begin{array}{l}\text { (i) Staphylococcus aureus } \\
\text { (ii) Streptococcus spp. } \\
\text { (iii) Diplocoques Gram+ }\end{array}$ & $\begin{array}{l}\text { (i) Coagulase-negative Staphylococci } \\
\text { (ii) Streptococcus spp. } \\
\text { (iii) Yeasts }\end{array}$ \\
\hline & $\begin{array}{l}\text { Use of disinfectants } \\
\text { Disinfectant } 1\end{array}$ & Disinfectant 2 & Disinfectant 3 \\
\hline $\begin{array}{l}\text { After using disinfectant } \\
\text { Two hours after using } \\
\text { disinfectant }\end{array}$ & $\begin{array}{l}\text { Absence of germs } \\
\text { (i) Staphylococcus aureus }\end{array}$ & $\begin{array}{l}\text { Absence of germs } \\
\text { (i) Staphylococcus aureus } \\
\text { (ii) Streptococcus spp. }\end{array}$ & $\begin{array}{l}\text { Absence of germs } \\
\text { (i) Coagulase-Staphylococci } \\
\text { (ii) Staphylococcus aureus }\end{array}$ \\
\hline \multirow{2}{*}{$\begin{array}{l}\text { Four hours after } \\
\text { using disinfectant }\end{array}$} & (i) Staphylococcus aureus & (i) Streptococcus spp. & $\begin{array}{l}\text { (i) Coagulase-negative Staphylococci } \\
\text { Streptococcus spp. }\end{array}$ \\
\hline & (ii) Streptococcus spp. & $\begin{array}{l}\text { (ii) Enterococcus spp. } \\
\text { (iii) Staphylococcus aureus }\end{array}$ & (ii) Enterococcus spp. \\
\hline \multirow{4}{*}{$\begin{array}{l}\text { Six hours after } \\
\text { using disinfectant }\end{array}$} & (i) Staphylococcus aureus & (i) Staphylococcus aureus & $\begin{array}{l}\text { (i) Coagulase-negative Staphylococci } \\
\text { Streptococcus spp. }\end{array}$ \\
\hline & (ii) Coagulase-negative Staphylococci & \multirow{3}{*}{$\begin{array}{l}\text { (ii) Streptococcus spp. } \\
\text { (iii) } \\
\text { Coagulase - Staphylococci } \\
\text { (iv) Pseudomonas luteola } \\
\text { (v) Yeasts }\end{array}$} & (ii) Enterococcus spp. \\
\hline & (iii) Streptococcus spp. & & \multirow{2}{*}{ (iii) Yeasts } \\
\hline & $\begin{array}{l}\text { (iv) Pantoea spp } \\
\text { (v) Yeasts }\end{array}$ & & \\
\hline
\end{tabular}

(5\% $\mathrm{m} / \mathrm{m})$, polyaminopropyl biguanide CAS no. 27083-27- $8(1.6 \% \mathrm{~m} / \mathrm{m})$, and complexing agent.

\section{Discussion}

The hospital environment plays a very important role in the colonization and transmission of opportunistic pathogens. Moreover, the microorganisms responsible for hospitalacquired infections can survive for days, weeks, or even months on hospital surfaces [21, 22]. For this reason, it is necessary to carry out microbiological monitoring of the hospital environment to find out the strains circulating in this environment. Our study, which is to the best of our knowledge the first to be carried out in this hospital center, shows that $83 \%$ of sites are contaminated compared to $17 \%$ which are not. Moreover, results show the increase in surface contamination in the men's and women's surgery departments that could be justified by the free access of patients. The contamination of operating theater is justified by the poor quality of disinfection and cleaning procedures 
between surgical operations, despite the limited access of patients and nursing staff, and by the multitude of surgical specialties in these departments.

The most contaminated sites are the floor, door handles, and bed rails, due to their frequent use by patients and nursing staff, as these sites are close to the patient, and this has been justified by several studies $[23,24]$.

The majority of bacteria isolated from the different studied services' surfaces are Gram-positive germs. This result is similar to those reported in a study carried out in a hospital center in Fez and contradicts other studies $[4,13,25]$. This contradiction could be due to the hospital size (especially its bed capacity) and the studied department specificity, as our study was carried out more precisely in the surgery departments of a small hospital center, while the other studies were carried out in other departments. It could also be due to the nature of care lavished in the departments and the disinfection method, as well as the visitors' access to the departments especially the open access ones. According to Shmitt et al., the environment constitutes a reservoir for Gram-positive bacteria, widely dispersed by human activity. These bacteria are more resistant to desiccation than Gramnegative bacteria, especially if the surfaces undergo only twice daily cleaning [26].

This study has shown that the most existing strains belong to the Staphylococcus family (40\%) and are distributed between Staphylococcus aureus (18\%) and coagulase-negative Staphylococcus (22\%). The presence of these two species could indicate a lack of hygiene in the hospital environment. The Staphylococci survive for several days on the surfaces [27]. Moreover, Staphylococcus has been found in a variety of sites including both community and hospital settings, particularly in surgery which can represent a very high risk of contracting an operative site infection for patients [28].

The second part of this work was based on the extraction model of the association rules, which has been applied for the first time, to the best of our knowledge, to surface sites and isolated germs in the hospital environment. The obtained results show that there are strong links between the contamination of the sampling sites and the isolated germs. This has made it possible to optimize the sampling, cleaning, and disinfection scenarios of the most contaminated sites, as well as knowing the behavior and profile of germs circulating in the different sites.

In the present study, a strong association was found between wall and nightstand's and door cuff's contaminations, meaning that the existence of contamination in wall and nightstand systematically indicates that door cuff is contaminated. Strong associations between ground and door cuff and bed rails were also found meaning that the existence of the contamination of ground and door cuff systematically indicates that bed rails are contaminated. Another strong association of contamination between door cuff and nightstand and bed rails means that the existence of contamination in door cuff and nightstand indicates systematically that bed rails are contaminated, and finally a strong association between door cuff and nightstand and ground means that the existence of door cuff and nightstand contamination systematically indicates that ground is contaminated. This increases the rate of optimization of intervention time and the effectiveness of disinfectant chosen (Table 1).

Concerning the germs' association, strong association of presence found between Pseudomonas luteola and coagulase-negative Staphylococcus means that the presence of Pseudomonas luteola indicates that coagulase-negative Staphylococcus exists. Moreover, the strong association between Staphylococcus aureus, Streptococcus spp., and coagulase-negative Staphylococcus shows that the presence of Staphylococcus aureus and Streptococcus spp. indicates the presence of coagulase-negative Staphylococcus.

There is a strong association between Escherichia coli or Staphylococcus aureus with coagulase-negative Staphylococci meaning that the presence of Escherichia coli as well as Staphylococcus aureus indicates the presence of coagulasenegative Staphylococci, which explains the nature and the profiles of germs circulating in the services. This association justifies the coexistence of bacteria within the same community and explains why each bacterial cell maintains a network of relations with its neighbors. Indeed, the cells of different bacterial species are not distributed homogeneously; they are rather modeled by their interactions with the neighboring cells and the abiotic environmental factors according to their metabolic and physiological needs [29].

The disinfection procedure evaluation after the use of three disinfectants has shown a total absence of germs immediately after the disinfection; the presence of Grampositive bacteria 2 hours after disinfection; a multiple presence of Gram-positive and negative bacteria $4 \mathrm{~h}$ after, and the multiplication of bacteria and the presence of yeasts 6 hours after disinfection. These results suggest the necessity to renew the disinfection of each site every 4 hours to reduce the risk of hospital surfaces contamination and thereby the risk of nosocomial infections occurrence. These findings are consistent with several studies having shown that the regular disinfection of hospital environment reduces significantly the potential risk of nosocomial infection [30, 31], which demonstrates the role of the hospital environment in nosocomial infections and constitutes data support that can be used to identify the transmission mode of environmental microbes to patients.

\section{Conclusion}

This study allowed us to know the germs circulating in the different surgical departments, whose identification revealed the predominance of Staphylococci which can be caused by infection of the operating site. Moreover, strong associations of contamination of the sampling sites and the germs have been found indicating a cross-contamination from one site to another with diversification of germs, thanks to the application of an innovative model approach for extracting association rules. Concerning the evaluation of the disinfection procedure efficiency of the most contaminated points in hospital surfaces, results showed that it is necessary to repeat the disinfection procedure at least every 4 hours to control the risk of surface infection, and thereby the risk of nosocomial infections occurs. 


\section{Data Availability}

The data used to support the findings of this study are available from the corresponding author upon request.

\section{Ethical Approval}

The study was ethically approved by the Fez-Meknes regional health steering committee under authorization no. DRS Fez-Meknes: 2146.04.2018.

\section{Conflicts of Interest}

The authors declare no conflicts of interest.

\section{Acknowledgments}

The authors would like to thank the Fez-Meknes regional health directorate. They also thank the team and health professionals of the Ibn Baja Taza provincial hospital center and the public health laboratory of the delegation of the Ministry of Health in Taza for their collaboration, their patience, and their precious help.

\section{References}

[1] World Health Organization, "Document technique. Lutte contre les infections et soins de santé: nécessité d'une action de collaboration," WHO Comité régional de la Méditerranée orientale, p. 1, 2010.

[2] B. Sahiledengle, F. Seyoum, D. Abebe, and E. N. Geleta, "Incidence and risk factors for hospital-acquired infection among paediatric patients in a teaching hospital: a prospective study in southeast Ethiopia," BMJ Open, vol. 10, no. 12, Article ID e037997, 2020.

[3] A. Farah, H. Zaroual, A. El Ouali Lalami et al., "Antimicrobial activity of Lavandula stoechas phenolic extracts against pathogenic bacteria isolated from a hospital in Morocco," Vegetos, vol. 33, no. 4, pp. 703-711, 2020.

[4] S. Berrada, G. B. Touimi, L. Bennani et al., "Exploration microbiologique des surfaces d'un centre d'hémodialyse de la ville de Fès: étude descriptive transversale," Revue Francophone Internationale de Recherche Infirmière, vol. 3, no. 2, pp. 120-128, 2017.

[5] C. Dussart, "Safety evaluation of individual pillboxes to control cross-contamination in the drug circuit in hospitals," International Journal of Environmental Research and Public Health, vol. 16, no. 20, p. 3878, 2019 p.

[6] T. Iwase, K. Seki, H. Shinji, Y. Mizunoe, and S. Masuda, "Development of a real-time PCR assay for the detection and identification of staphylococcus capitis, Staphylococcus haemolyticus and staphylococcus warneri," Journal of Medical Microbiology, vol. 56, no. 10, pp. 1346-1349, 2007.

[7] S. Alibi, "Occurrence of Corynebacterium striatum as an emerging antibiotic-resistant nosocomial pathogen in a Tunisian hospital," Scientific Reports, vol. 7, no. 1, pp. 1-8, 2017.

[8] L. Martínez-Martínez, A. I. Suárez, J. Rodríguez-Baño, K. Bernard, and M. A. Muniáin, "Clinical significance of corynebacterium striatum isolated from human samples," Clinical Microbiology and Infection, vol. 3, no. 6, pp. 634-639, 1997.
[9] G. Caggiano, C. Napoli, C. Coretti et al., "Mold contamination in a controlled hospital environment: a 3-year surveillance in southern Italy," BMC Infectious Diseases, vol. 14, no. 1, pp. 1-5, 2014.

[10] E. H. Ahmed, H. A. M. Hassan, N. M. El-Sherbiny, and A. Soliman, "Bacteriological monitoring of inanimate surfaces and equipment in some referral hospitals in assiut city, Egypt," International Journal of Microbiology, vol. 2019, Article ID 5907507, 9 pages, 2019.

[11] A. Vandini, R. Temmerman, A. Frabetti et al., "Hard surface biocontrol in hospitals using microbial-based cleaning products," Plos one, vol. 9, no. 9, Article ID e108598, 2014.

[12] S. Natoubi, A. Barguigua, S. B. Zriouil et al., "Incidence of extended-spectrum Be-ta-lactamase-producing Klebsiella pneumoniae among patients and in the environment of hassan II hospital, settat, Morocco," Advances in Microbiology, vol. 06, no. 03, pp. 152-161, 2016.

[13] A. El Ouali Lalami, H. Touijer, F. El-Akhal et al., "Microbiological monitoring of environment surfaces in a hospital in Fez city, Morocco," Journal of Materials and Environmental Science, vol. 7, no. 1, pp. 123-130, 2016.

[14] D. J. Weber, W. A. Rutala, M. B. Miller, and K. E. Huslage, "Role of hospital surfaces in the transmission of emerging healthcare-associated pathogens: nor-ovirus, Clostridium difficile, and acinetobacter species," American Journal of Infection Control, vol. 38, no. 5, pp. S25-S33, 2010.

[15] F. Santé publique, "Enquête nationale de prévalence des infections nosocomiales et des traitements anti-infectieux en établissements de santé, mai-juin 2017.Saint-Maurice," 2019, https://www.santepubliquefrance.fr.

[16] S. Matinyi, M. Enoch, D. Akia et al., "Contamination of microbial pathogens and their antimicrobial pattern in operating theatres of peri-urban eastern Uganda: a cross-sectional study," BMC Infectious Diseases, vol. 18, no. 1, pp. 1-9, 2018.

[17] Centers for Disease Control and Prevention/Healthcare Infection Control Advisory Committee (HICPAC), "Guidelines for environmental infection control in healthcare facilities environ-mental surfaces, E.VI. B.2. and E.I.E.3," Atlanta [GA]: Centers for Disease Control and Prevention, 2003.

[18] I. Norme, "Salles propres et environnements maîtrisés apparentés, maîtrise de la biocontamination," AFNOR-Association Française de Normalisation, pp. 14698-14701, 2004.

[19] Ministry of Social Affairs and Health, Surveillance Microbiologique de L'Environnement Dans'Etablissements de Sante Air, eau et Surfaces, Ministry of Social Affairs and Health, Helsinki, Finland, 2016.

[20] R. Agrawal, I. Tomasz, and S. Arun, "Mining association rules between sets of items in large databases," in Proceedings of the 1993 ACM SIGMOD. International Conference on Management of Data, Washington, DC, USA, June 1993.

[21] G. Suleyman and G. Alangaden, "The role of environmental contamination in the transmission of nosocomial pathogens and healthcare-associated infections," Current Infectious Disease Reports, vol. 20, no. 6, pp. 1-11, 2018.

[22] J. E. Wißmann, L. Kirchhoff, Y. Brüggemann et al., "Persistence of pathogens on inanimate surfaces: a narrative review," Microorganisms, vol. 9, no. 2, p. 343, 2021.

[23] J. Dancer Stephanie, "Controlling hospital-acquired infection: focus on the role of the environment and new technologies for decontamination," Clinical Microbiology Reviews, vol. 27, no. 4, pp. 665-690, 2014.

[24] A. Ramzi, B. Oumokhtar, M. Filali, Touria et al., "Evaluation of antibacterial activity of three quaternary ammonium 
disinfectants on different germs isolated from the hospital environment," BioMed Research International, vol. 2020, Article ID 6509740, 6 pages, 2020.

[25] S. Jaouhar, A. El Ouali Lalami, K. Ouarrak et al., "Infectious risk of the hospital environment in the center of Morocco: a case of care unit surfaces," Scientifica, vol. 2020, Article ID 1318480, 7 pages, 2020.

[26] A. Schmitt, N. Glasser, D. Steinbach, and O. Meunier, "Études expérimentales de l'effet rémanent d'un détergent désinfectant pour surfaces sur une souche d'Escherichia coli," Pathologie Biologie, vol. 57, no. 6, pp. 463-469, 2009.

[27] M. G. Schmidt, H. H. Attaway, P. A. Sharpe et al., "Sustained reduction of microbial burden on common hospital surfaces through introduction of copper," Journal of Clinical Microbiology, vol. 50, no. 7, pp. 2217-2223, 2012.

[28] D. S. Oliveira, W. Clovis, D. S. De-Melo-Martins, A. Carlos et al., "Microbiological characterization of the surface contamination in surgical room areas in a hospital in Sao Paulo (Brazil)," Infection, vol. 18, no. 4, pp. 130-134, 2014.

[29] R. Stubbendieck, C. Vargas-Bautista, and D. Paul, "Bacterial communities: interactions to scale," Frontiers in Microbiology, vol. 7, p. 1234, 2016.

[30] M. Dettenkofer, S. Wenzler, S. Amthor, G. Antes, E. Motschall, and F. D. Daschner, "Does disinfection of environmental surfaces influence nosocomial infection rates? a systematic review," American Journal of Infection Control, vol. 32, no. 2, pp. 84-89, 2004.

[31] G. E. Morfill, T. Shimizu, B. Steffes, and H. Schmidt, "Nosocomial infections-a new approach towards preventive medicine using plasmas," New Journal of Physics, vol. 11, no. 11, pp. 115-119, 2009. 